\title{
KOMUNIKASI PENGAWAS DALAM MENINGKATKAN KINERJA GURU SEKOLAH DASAR DI KECAMATAN SOMBA OPU KABUPATEN GOWA
}

\author{
KAMALUDDIN \\ Fakultas Dakwah dan Komunikasi \\ Universitas Islam Negeri Alauddin Makassar \\ Email : kamaluddintajibu@gmail.com
}

\begin{abstract}
:
The supervision process carried out by the Supervisor and Principal aims to improve the performance of the teachers. The teacher's performance includes the ability to prepare teaching materials, choose media learning, carry out learning and evaluate learning activities. For this reason supervisors in carrying out supervision activities must adopt a communication strategy that includes interpersonal communication, group communication and mass communication. However, in the implementation of supervision, supervisors experienced various obstacles including: Clarity of roles and tasks, Policy Structure, Communication Ability of Local and National Leader Support Supervisors.
\end{abstract}

Keywords: Communication strategy, personal communication, supervisors, and teacher

\section{PENDAHULUAN}

Pendidikan nasional juga sedang mengalami berbagai perubahan yang cukup mendasar, terutama berkaitan dengan Undang-Undang Sistem Pendidikan Nasional (Undang-Undang SISDIKNAS), manajemen, dan kurikulum, yang diikuti lainnya. Perubahan-perubahan tersebut diharapkan dapat memecahkan berbagai permasalahan pendidikan, baik masalah-masalah konvensional maupun masalah-masalah yang muncul bersamaan dengan hadirnya ide-ide baru (masalah Inovatif). Disamping itu, melalui perubahan tersebut diharapkan terciptanya iklim yang kondusif bagi peningkatan kualitas pendidikan, dan pengembangan sumber daya manusia (PSDM) untuk mempersiapkan bangsa Indonesia memasuki era kesengatan dan kesemrawutan global.

Pada era informasi dan komunikasi mendorong tingginya persaingan, persyaratan kerja, dan perubahan orientasi yang menuntut dunia pendidikan harus melakukan perubahan dan penyesuaian kompetensi lulusan. Penyelenggaraan 
pendidikan terkait dengan peningkatan mutu sumber daya Manusia (SDM) mengalami peningkatan. Dalam rangka perbaikan mutu pendidikan, pemerintah telah melakukan perbaikan kurikulum, peningkatan mutu guru, penyedian sarana dan prasarana, perbaikan kesejahteraan guru, perbaikan organisasi sekolah, perbaikan menajemen, pengawas dan perundang-undangan. Agar dapat menghasilkan kinerja yang baik, maka benar-benar mampu membuat perencanaan, pengorganisasian, pengarahan, dan mengadakan pengawas terhadap program dan kegiatan pendidikan.

Sekolah sebagai lembaga memiliki kinerja (performance) yang bermutu, bila pelaksanaan organisasi berdasarkan siklus manajemen diawali dengan penyusunan program, pembagian tugas yang teratur, pelaksanaan program, proses pelaksanaan diawasi dan hasilnya dievaluasi. Hasil evaluasi dijadikan untuk menyusun program baru, demikian seterusnya, sehingga merupakan siklus yang dinamis, berkembang menuju hasil yang baik. Oleh karena itu, sekolah harus senantiasa berupaya meningkatkan mutu pendidikan setiap tahunnya dengan memperhatikan komponen dasar yang mempengaruhi yaitu kurikulum dan proses pembelajaran, administrasi dan manajemen sekolah, organisasi dan kelembagaan sekolah, ketenagaan, pembiayaan sarana dan prasarana, peserta didik, masyarakat, serta lingkungan, dan budaya sekolah.

Pendidikan akan bermutu jika sesuai dengan apa yang diharapkan oleh masyarakat (bench mark) dapat dipenuhi. Apabila sebuah sekolah telah mencapai standar mutu yang dipersyaratkan, maka sekolah tersebut secara bertahap mampu mencapai mutu yang kompetitif baik yang bertaraf nasional maupun yang bertaraf internasional. Kemudian perlu menerapkan pengawas yang intensif, agar semua pelaksanan program dan kegiatan dapat memenuhi standar dan pencapaian terukur. Pengawas atau kontrol yang terukur dapat dilakukan dengan melaksanakan kegiatan supervisi baik yang dilakukan oleh pemerintah, pengawas sekolah, kepala sekolah, sejawat guru, dan stekeholders. Mengacu pada permasalahan di atas, maka penulis mencoba mengambil sebuah judul tesis tentang "Komunikasi Pengawas Dalam meningkatkan Kinerja Guru SD di Kecamatan Somba Opu Kabupaten Gowa".

Tujuan penelitian ini di dasarkan permasalahan yang dikemukakan di atas adalah :

1. Untuk mengetahui strategi Komunikasi Pengawas Dalam meningkatkan Kinerja Guru SD di Kecamatan Somba Opu Kabupaten Gowa.

2. Untuk mengetahui faktor-faktor yang berpengaruh terhadap strategi komunikasi pengawas dalam meningkatkan kinerja pendidik sekolah dasar di kecamatan Sombaopu Kabupaten GowaUntuk mengetahui Strategi Komunikasi Pengawas Dalam meningkatkan Kinerja Guru SD di Kecamatan Somba Opu Kabupaten Gowa. 


\section{TINJAUAN TEORITIS}

\section{A. Strategi Pengawas dalam melakukan supervisi}

Pengawas sekolah di kabupaten dan kota menurut Sagala (2008 :109) adalah pegawai negeri sipil yang diberi tugas, tanggungjawab dan wewenang oleh bupati atau walikota melakukan pengawas sekolah. Mengacu pada peraturan perundang-undangan yang ada, pengawas satuan pendidikan adalah berstatus sebagai pejabat fungsional. Keahlian yang dituntut dari jabatan pengawas berbeda dengan guru yang tercermin tugas pokok dan fungsinya serta tanggungjawabnya sebagai pengawas. Tugas pokok pengawas satuan pendidikan adalah membina dan mengawasi penyelenggaraan pendidikan baik teknis edukatif maupun teknis administratif pada satuan pendidikan tertentu.

Idealnya sebagai seorang pengawas disamping mengetahui jenis-jenis dan teknik-tehnik supervisi juga harus mengetahui kegiatan penting dalam pembelajaran. Karena pembelajaran merupakan kegiatan inti dari para pengawas. Untuk meningkatkan profesionalisme supervisor. Oleh karena itu para supervisor harus menguasai (1) pembelajaran yang lebih menekankan pada parktek, baik di laboratorium maupun di masyarakat dan dunia kerja (Dunia Usaha) (2) pembelajaran menjalin hubungan sekolah dan masyarakat dalam hal ini pengawas hendaknya mampu membantu setiap guru agar mampu dan jeli melihat berbagai potensi masyarakat yang bisa didayagunakan sebagai sumber belajar, (3) Pengawas mampu membantu guru untuk mengembangkan iklim pembelajaran yang demokratis, dan terbuka, melalui pembelajaran terpadu. (4) pembelajaran lebih ditekankan pada masalah-masalah aktual yang secara langsung berkaitan dengan kehidupan nyata yang ada di masyarakat dan (5) membantu guru agar mampu menerapkan dan mengembangkan suatu model pembelajaran "moving class", untuk setiap bidang studi, dan kelas merupakan laboratorium untuk masing-masing bidang studi.

Untuk lebih jelasnya, pelaku utama supervisi adalah Pengawas dan Kepala Sekolah itu sendiri. Dalam proses supervisi yang dilakukan oleh Pengawas dan Kepala Sekolah harus memetik manfaat dalam meningkatkan kinerja para guru. Salah satu dari kegiatan supervisi yang lakukan biasanya dengan strategi supervisi klinis. Strategi klinis ini di antaranya adalah:

a. Kegiatan supervisi akan berlangsung baik karena dapat mengumpulkan informasi yang tepat, langsung dari guru sendiri, yang memang diperlukan dan tepat untuk digunakan dalam pembinaan.

b. Pihak pengawas atau kepala sekolah yang melaksanakan supervisi akan merasa puas karena dapat memberikan bantuan yang tepat kepada guru yang memerlukan. 
c. Oleh karena supervisi dilaksanakan berdasarkan hasil diskusi bersama dengan guru dan dituliskan dalam bentuk perencanaan maka langkah kegiatannya menjadi pasti, setiap langkah dapat diikuti dan dicermati mana yang sudah dapat terlaksana dan mana yang belum, serta dapat dikaji ulang untuk meningkatkan di lain waktu.

d. Bagi Pendidik akan merasa lebih dekat dengan pengawas dan kepala sekolah sehingga lama kelamaan tidak ada lagi yang perlu ditutupi. Dalam kegiatan yang lain pun keterbukaan seperti itu akan tetap terpelihara. Situasi inilah yang akan membantu menciptakan iklim sekolah dengan suasana harmonis dan penuh kekeluargaan.

e. Pendidik merasa puas karena akan mendapat pembinaan yang sesuai dengan yang diperlukan, yaitu memecahkan masalah yang dijumpai secara tepat sasaran sehingga problematika mengajar akan dapat teratasi

f. Pihak Pengawas akan merasa puas karena dapat memberikan bantuan kepada Pendidik secara tepat seperti apa yang dibutuhkan oleh Pendidik. Selanjutnya hasil pembinaan dapat dirasakan oleh Pendidik dan berdampak pada peningkatan mutu pelajaran.

Untuk dapat menerapkan strategi komunikasi secara tepat, perlu memahami latar belakang dan isi program kegiatan yang akan dikembangkan. Bentuk-bentuk strategi komunikasi yang dapat diterapkan dalam melakukan pengawasan/supervisi konflik dapat dijelaskan sebagi berikut:

1. Komunikasi antar Pribadi (interpersonal communication)

Dalam kaitannya dengan strategi komunikasi antar pribadi (interpersonal) misalnya ditempuh melalui musyawarah atau perundingan yang dilakukan secara langsung di antara para pihak, yang menaruh perhatian dengan program yang akan disusun. Komunikasi yang terjadi didasarkan atas kesukerelaan antara berbagai pihak untuk memutuskan bentuk kegiatan yang cocok untuk dikembangkan. Proses komunikasi yang terjadi akan berbentuk perundingan, negosiasi, musyawarah dan bentuk pertemuan tatap muka lainnya yang dapat disesuaikan dengan kondisi lokal merupakan inti pendekatan komunikasi antar pribadi. Fisher dan Ury (dalam Hadi, 2004) menyebutkan bahwa rnusyawarah atau negosiasi adalah cara mendasar untuk mendapatkan dari pihak lain.

2. Komunikasi Massa (mass communication)

Devito (1982) mendefinisikan komunikasi massa sebagai komunikasi yang menggunakan media massa, baik cetak (surat kabar, majalah) atau elektronik (radio, televisi), yang dikelola oleh suatu lembaga yang ditujukan kepada sejumlah besar orang yang tersebar di banyak tempat, anonim dan heterogen. Proses komunikasi yang berlangsung dimana pesannya dikirim dari sumber yang melembaga kepada khalayak yang sifatnya massal melalui alatalat yang bersifat mekanik seperti; radio, televisi, surat kabar dan film. Pesan- 
pesan bersifat umum, disampaikan secara cepat, serentak dan selintas (khususnya media elektronik). Komunikasi antar pribadi, komunikasi kelompok dan komunikasi organisasi berlangsung juga dalam proses untuk mempersiapkan pesan yang disampaikan media massa ini.

Fungsi komunikasi melalui media massa adalah (a) menyiarkan informasi (to inform), (b) mendidik (to educate) dan (c) menghibur (to entertain) yang fungsinya diprioritaskan sesuai dengan jenis-jenis media massa. Dalarn komunikasi melalui media massa terjadi umpan balik secara tidak langsung (delayed feedback).

3. Komunikasi Publik (public communication)

Pace (1979) menyatakan bahwa komunikasi publik adalah proses komunikasi dimana pesan-pesan disampaikan oleh pembicara dalam situasi tatap muka di depan khalayak yang lebih besar dan tidak dikenali satu persatu. Disebut juga sebagai komunikasi kelompok besar (large group communication) melalui komunikasi pidato, komunikasi retorika, public speaking.

Komunikasi publik berlangsung secara lebih formal, dituntut persiapan pesan yang cermat, keberanian dan keahlian menghadapi sejumlah besar orang dan diperlukan daya tarik fisik, keahlian dan kejujuran pembicara dapat menentukan efektifitas penyampaian pesan.

Selanjutnya Pace (1979) menyatak.an ciri bentuk komunikasi ini adalah: satu pihak (pendengar) cenderung lebih pasif, interaksi antara sumber terbatas, dilakukan ditempat umum seperti dikelas, auditorium tempat ibadah, dihadiri oleh sejumlah besar orang, biasanya telah direncanakan, sering bertujuan untuk memberikan penerangan, rnenghibur, memberikan penghormatan dan membujuk.

4. Komunikasi Kelompok (group communication)

Arifin (1994) menyatakan bahwa komunikasi kelompok adalah komunikasi yang berlangsung di antara beberapa orang dalam suatu kelompok kecil seperti dalam rapat, pertemuan, konferensi dan sebagainya.

Komunikasi kelompok merupakan bentuk komunikasi sekumpulan orang yang mempunyai tujuan bersama, yang berinteraksi satu sama lain untuk mencapai tujuan bersama, mengenal satu sama lainnya dan memandang mereka sebagai bagian dari kelompok tersebut contohnya seperti; keluarga, kelompok studi dan kelompok diskusi yang dapat juga terjadi pada kelompok kecil (small group communications). Pace (1979). Komunikasi kelompok memiliki kesamaan dengan komunikasi antar pribadi dan komunikasi publik karena dilaksanakan melalui tatap muka dan bersifat dialogis, serta berlangsung dua arah. Perbedaan antara kedua jenis komunikasi ini adalah 
terletak pada jumlah khalayaknya, jika kelompoknya kecil, maka akan memungkinkan situasi komunikasi dialogis, tetapi apabila dalam kelornpok besar maka tidak memungkinkan situasi dialogis meskipun antara komunikator dan komunikan bertatap muka (face to face).

Effendy (2004) menyatakan bahwa keuntungan dari komunikasi tatap muka (face to face communication) dalam situasi komunikasi antar pribadi dan komunikasi kelompok ialah terjadinya umpan balik langsung. Artinya komunikator dapat mengetahui tanggapan dari komunikan dengan segera pada saat itu juga. Dengan demikjan ia akan dapat mengubah teknik dan strategi berkornunikasi bila tampak adanya tanda-tanda kegagalan dalam proses penyampaian pesan kepada khalayaknya.

Strategi komunikasi merupakan suatu paduan perencanaan komunikasi (communication planning) dengan manajemen komunikasi (communication managemen) untuk mencapai tujuan yang telah ditetapkan (Effendy: 2004). Dengan demikian strategi dalam konteks komunikasi harus dapat berperan dalarn tindakan operasional dengan memanfaatkan secara efektif sumberdaya komunikasi.

\section{B. Faktor-faktor yang berpengaruh terhadap strategi komunikasi Pengawas}

Dalam melaksanakan berbagai strategi kebijakan yang ditempuh, terkadang banyak hal yang turut berpengaruh dalam pelaksanaannya. Rondinelli dan Chemma (1983) menyebutkan faktor-faktor yang dipandang mempengaruhi pelaksanaan sebuah strategi, antara lain:

\section{1) Environmental Conditions}

Environmental Conditions, melingkupi berbagai faktor, seperti struktur politik nasional, proses perumusan strategi, instruktur politik, dan supra struktur politik ditingkat lokal, sosial budaya dan berbagai organisasi kepentingan, serta tersedianya sarana dan prasarana fisik. Suatu strategi pada hakekatnya timbul dari suatu lingkungan sosial, ekonomi dan politik yang khusus dan kompleks. Hal ini akan mewarnai bukan hanya substansi strategi itu sendiri, melainkan juga pola hubungan interorganisasi dan karakteristik badan-badan pelaksana di lapangan, serta potensi sumberdaya manusia, baik jumlah maupun macamnya. Struktur politik nasional, ideologi, dan proses perumusan strategi ikut mempengaruhi tingkat dan arah kegiatan yang ditempuh. Di samping itu karakteristik struktur lokal, kelompok-kelompok sosial budaya yang terlibat dalam perumusan kebijaksanaan, dan tingkat organisasi kepentingan serta kondisi infra struktur politik, juga memainkan peranan penting dalam pelaksnaan strategi yang dipilih.

\section{2) Interorganizational Relationship}

Interorganizational relationship, meliputi beberapa faktor seperti kejelasan dan sistem program, pengalokasian fungsi, perencanaan, penganggaran, pelaksanaan prosedur, komunikasi antar organisasi, dan efektivitas hubungan 
antar organisasi. Keberhasilan pelaksanaan staregi pembelajaran memerlukan kerjasama dan interaksi dengan sejumlah organisasi pada tingkat lembaga itu sendiri serta kerjasama dengan lembaga-lembaga di luar sekolah tersebut maupun di kalangan kelompok-kelompok yang berkepentingan.

\section{3) Resources for policy and Program Implementation.}

Resources for policy and program implementation, meliputi beberapa faktor seperti, pengawasan dana, kecukupan anggaran, dukungan pemimpin nansional, lokal, dan dukungan birokrasi pusat. Kondisi lingkungan yang kondusif dalam arti dapat memberikan diskresi yang lebih luas kepada para pengelola, dan hubungan interorganisasi yang sangat efektif sangat diperlukan bagi terlaksananya strategi yang dipilih. Sampai sejauhmana para pengelola memiliki keleluasaan untuk merencanakan dan menggunakan uang, mengalokasikan anggaran atau membiayai keperluan urusan, ketepatan waktu dalam mengalokasikan pembiayaan kepada badan pelaksana, kewenagan untuk memungut sumbersumber keuangan dan kewenangan untuk membelanjakannya juga mempengaruhi pelaksanaan strategi yang dipilih.

\section{4) Characteristic of implementing agencies}

Characteristic of implementing agencies, diutamakan kepada kemampuan para pelaksana di bidang keterampilan teknik, manajerial dan politik dalam pelaksanaan program. Kemampuan untuk merencanakan, mengkoordinasikan, mengendalikan dan mengintegrasikan setiap strategi keputusan, baik yang berasal dari sub-sub unit organisasi, maupun dukungan yang datang dan lembaga politik nasional dan pejabat pemerintah pusat lainnya. Hakekat dan kualitas komunikasi internal, hubungan antar dinas pelaksana dengan masyarakat, dan keterkaitan secara efektif dengan swasta dan lembaga swadaya masyarakat memegang peranan penting dalam pelaksanaan setiap strategi. Hal yang sama juga adalah kepemimpinan yang berkualitas, komitmen staf terhadap tujuan strategi yang dipilih.

\section{METODE PENELITIAN}

Penelitian ini dilaksanakan secara langsung pada lokasi sekolah umum pada SD di kecamatan Somba Opu Kabupaten Gowa selama tiga bulan, mulai 1 September sampai 1 Desemberi 2019.

Penelitian ini menggunakan tipe penelitian deskriptif kualitatif, dengan maksud untuk mendeskripsikan informasi-informasi yang berhungan dengan strategi komunikasi pengawas serta faktor-faktor yang mempengaruhinya.

Pendekatan penelitian yang digunakan adalah komunikasi pendidikan. Maksudnya penelitian ini dikaji dalam bidang komunikasi pendidikan. Pada 
penelitian ini yang menjadi populasi adalah semua pengawas, Kepala sekolah dan Pendidik pada SD di kecamatan Somba Opu kabupaten Gowa. Penetapan informan diolakukan secara purporsive. Sehingga jumlah informan dalam penelitian ini sebanyak 15 orang yang terdiri dari 3 orang pengawas, 3 orang kepala sekolah serta 9 orang pendidik.

Jenis data yang digunakan dalam penelitian ini adalah data primer dan data sekunder

1. Sumber data

a. Data primer yang diperoleh dari hasil wawancara dengan pihak Pengawas, Kepala Sekolah,Pendidik pada SD di kecamatan Somba Opu Kab. Gowa.

b. Data sekunder, yaitu data yang melalui dokumentasi, artikel, surat kabar yang berkaitan dengan dunia pendidikan.

Dilakukan Wawancara langsung dengan key informan (Pengawas, Kepala Sekolah,dan Pendidik). Observasi, yaitu mengadakan pengamatan langsung terhadap kegiatan pengajaran. Studi pustaka, yaitu data yang diperoleh dari kajian literatur-literatur dan laporan-laporan yang berkaitan dengan objek penelitian.

Sementara teknik analisa data yang digunakan adalah deskriptif-kualitatif, yaitu untuk menganalisa sikap dan pendapat key informan (Pengawas, Kepala Sekolah,dan Pendidik pada SD di kecamatan Somba Opu kabupaten Gowa). Kemudian berusaha mengumpulkan dan menyajikan data sehingga dapat memberikan gambaran yang cukup jelas atas objek yang diteliti.

\section{HASIL DAN PEMBAHASAN}

\section{Strategi Komunikasi Pengawas dalam melakukan supervisi}

Untuk dapat menerapkan strategi komunikasi secara tepat, perlu memahami latar belakang dan isi dan tujuan kegiatan yang akan dikembangkan. Bentuk-bentuk strategi komunikasi yang dapat diterapkan dalam melakukan pengawasan/supervisi dapat dijelaskan sebagai berikut:

a. Komunikasi antar Pribadi (interpersonal communication)

Dalam kaitannya dengan strategi komunikasi antar pribadi (interpersonal), hasil pengamatan penulis umumnya dilakukan oleh kepala sekolah pada saat pra pembelajaran, inti pembelajaran dan akhir pembelajaran. Strategi ini digunakan difokuskan pada kesiapan guru menyiapkan Rencana program Pembelajaran (RPP). Seperti yang diungkapkan oleh salah seorang informan kepala sekolah sebagai berikut:

...sebelum guru melakukan kegiatan pembelajaran, sebagai kepala sekolah kita memeriksa ketepatan rancangan pembelajarannya. Pada saat itu kita membantu ia (guru) untuk menyusun RPP yang benar. Hal itu dilakukan agar guru benar-benar menyusun RPP sesuai dengan 
kurikulum yang berlaku. (Wawancara, Oktober 2018)

Kegiatan itu juga diperkuat oleh salah seorang informan dari guru yang mengemukakan sebagai berikut:

...sebelum kita melaksanakan kegiatan pembelajaran, kita memperlihatkan RPP kita kepada kepala sekolah. Hal itu saya lakukan agar terjadi perbaikan RPP sebelum materi itu saya ajarkan dikelas. (wawancara, Oktober 2018).

Dari informasi itu, maka dapat disimpulkan bahwa komunikasi antarpribadi dalam kegiatan supervisi pertama terjadi ketika kepala sekolah memeriksa RPP yang disusun oleh guru yang bersangkutan. Tujuan dari kegiatan awal ini adalah membantu para guru untuk menyusun RRP yang akan diajarkan kepada para peserta didik.

Dengan tidak mempersoalkan apa yang dilakukan kepala sekolah melalui komunikasi antar pribadi, beberapa pelajaran berharga yang dapat kita simak dari kegiatan itu. Antara lain; 1) melalui komunikasi antarpribadi tercipta hubungan yang saling menguatkan. 2) terciptanya sikap keterbukaan. Komunikasi yang terjadi didasarkan atas kesukerelaan antara berbagai pihak untuk memutuskan bentuk kegiatan yang cocok untuk dikembangkan. Proses komunikasi yang terjadi akan berbentuk perundingan, negosiasi, musyawarah dan bentuk pertemuan tatap muka lainnya yang dapat disesuaikan dengan kondisi lokal merupakan inti pendekatan komunikasi antar pribadi. Fisher dan Ury (dalam Hadi, 2004) menyebutkan bahwa rnusyawarah atau negosiasi adalah cara mendasar untuk mendapatkan dari pihak lain.

\section{Komunikasi Massa (mass communication)}

Devito (1982) mendefinisikan komunikasi massa sebagai komunikasi yang menggunakan media massa, baik cetak (surat kabar, majalah) atau elektronik (radio, televisi), yang dikelola oleh suatu lembaga yang ditujukan kepada sejumlah besar orang yang tersebar di banyak tempat, anonim dan heterogen. Proses komunikasi yang berlangsung dimana pesannya dikirim dari sumber yang melembaga kepada khalayak yang sifatnya massal melalui alatalat yang bersifat mekanik seperti; radio, televisi, surat kabar dan film. Pesanpesan bersifat umum, disampaikan secara cepat, serentak dan selintas (khususnya media elektronik). Komunikasi antar pribadi, komunikasi kelompok dan komunikasi organisasi berlangsung juga dalam proses untuk mempersiapkan pesan yang disampaikan media massa ini.

Fungsi komunikasi melalui media massa adalah (a) menyiarkan informasi (to inform), (b) mendidik (to educate) dan (c) menghibur (to 
entertain) yang fungsinya diprioritaskan sesuai dengan jenis-jenis media massa. Dalarn komunikasi melalui media massa terjadi umpan balik secara tidak langsung (delayed feedback). Pada komunikasi massa, komunikator tidak dapat mengetahui dengan segera apakah komunikasinya berhasil atau gagal. Untuk mencapai keberhasilan kegiatan komunikasi yang menggunakan media massa diperlukan pemahaman yang menyelul'uh atas cakupan unsurunsur seperti sifat komunikator, sifat pesan, sifat media massa dan sifat komunikan.

\section{Komunikasi Publik (public communication)}

Pace (1979) menyatakan bahwa komunikasi publik adalah proses komunikasi dimana pesan-pesan disampaikan oleh pembicara dalam situasi tatap muka di depan khalayak yang lebih besar dan tidak dikenali satu persatu. Disebut juga sebagai komunikasi kelompok besar (large group communication) melalui komunikasi pidato, komunikasi retorika, public speaking.

Komunikasi publik berlangsung secara lebih formal, dituntut persiapan pesan yang cermat, keberanian dan keahlian menghadapi sejumlah besar orang dan diperlukan daya tarik fisik, keahlian dan kejujuran pembicara dapat menentukan efektifitas penyampaian pesan.

Selanjutnya Pace (1979) menyatak.an ciri bentuk komunikasi ini adalah: satu pihak (pendengar) cenderung lebih pasif, interaksi antara sumber terbatas, dilakukan ditempat umum seperti dikelas, auditorium tempat ibadah, dihadiri oleh sejumlah besar orang, biasanya telah direncanakan, sering bertujuan untuk memberikan penerangan, rnenghibur, memberikan penghormatan dan membujuk.

\section{Komunikasi Kelompok (group communication)}

Arifin (1994) menyatakan bahwa komunikasi kelompok adalah komunikasi yang berlangsung di antara beberapa orang dalam suatu kelompok kecil seperti dalam rapat, pertemuan, konferensi dan sebagainya.

Komunikasi kelompok merupakan bentuk komunikasi sekumpulan orang yang mempunyai tujuan bersama, yang berinteraksi satu sama lain untuk mencapai tujuan bersama, mengenal satu sama lainnya dan memandang mereka sebagai bagian dari kelompok tersebut contohnya seperti; keluarga, kelompok studi dan kelompok diskusi yang dapat juga terjadi pada kelompok kecil (small group communications). Pace (1979). Komunikasi kelompok memiliki kesamaan dengan komunikasi antar pribadi dan komunikasi publik karena dilaksanakan melalui tatap muka dan bersifat dialogis, serta berlangsung dua arah. Perbedaan antara kedua jenis komunikasi ini adalah terletak pada jumlah khalayaknya, jika kelompoknya kecil, maka akan memungkinkan situasi komunikasi dialogis, tetapi apabila dalam kelornpok besar maka tidak memungkinkan situasi dialogis meskipun antara komunikator dan komunikan bertatap muka (face to face) 


\section{Faktor- Faktor yang berpengaruh terhadap strategi komunikasi}

Aktivitas supervisi merupakan kegiatan yang terencana. Kegiatannya diarahkan pada sasaran maupun tujuan yang ingin dicapai. Akan tetapi dalam melakukan kegiatannya, berbagai faktor yang turut berpengaruh. Dari hasil observasi dan wawancara penulis dapat dikemukakan faktor-faktor yang turut berpengaruh dalam pelaksanaan supervisi, sebagai berikut:

\section{a. Kejelasan peran dan tugas}

Supervisi terkadang merupakan bagian dari kegiatan kepala sekolah. Maksudnya, supervisor pendidikan bukan hanya terdiri dari pengawas atau penilik, melainkang kegiatan supervisi dapat juga di lakukan kepala sekolah. Seorang supervisor yang kebetulan juga adalah kepala sekolah pasti diperhadapkan pada berbagai peran dan tanggung jawab, seperti yang dikemukakan oleh salah seorang kepala sekolah sebagai berikut:

... Sebagai kepala sekolah kita dihadapkan pada beberapa tugas dan peran. Adapun peran dan tugas yang dimaksud melipuri fungsi: 1) educator, 2) manajer, 3) administrator, 4) supervisor, 5) pemimpin (leader), 6) inovator, 7) Motivator. Setiap peran dan tugas tersebut memiliki tanggungjawab masing-masing, dan terkadang peran dan tugas itu harus dilaksanakan secara bersamaan. (wawancara, Oktober 2018).

Uraian tersebut menunjukkan bahwa sebagai pengawas sekaligus kepala sekolah, tugas supervisi adalah salah tanggungjawab yang diembannya. Akibatnya terkadang dalam pelaksanaan kegiatan supervisi terkesan asal memenuhi kewajiban tampa memperhatikan tujuan akhir dari kegiatan supervisi.

Untuk mengatasi hal itu menurut penulis, seorang supervisor, sebaiknya dipilih berdasarkan pengalaman kerja, dan sebaiknya tidak terlalu diberikan beban kerja serta jabatan yang ganda. Melalui proses itu, tentunya akan tercipta supervisor yang profesional, sehingga mampu memberikan pelayanan maksimal dan pengembangan kegiatan guru secara maksimal pula. Hal itu penting karena setiap individu, pasti memiliki keinginan untuk melakukan sesuatu tugas dan tanggungjawab secara maksimal.

\section{b. Struktur Kebijakan}

Kegiatan pendidikan adalah suatu kegiatan yang diselenggarakan dan dilaksanakan dengan berbagai peraturan dan kebijakan. Maksud aturan dan kebijakan itu baik, yaitu agar tujuan pendidikan itu dapat dimaksimalkan. Akan tetapi ketika sampai ditingkat operasional dan pengejewantahan kebijakan itu, terkadang tidak berjalan maksimal. Atas dasar itu, penulis berpendapat bahwa struktur kebijakan akan mempengaruhi kegiatan pengawas 
(supervisor) di lapangan. Pernyataan penulis diperkuat dengan pendapat seorang pengawas sebagai berikut:

...dalam penetapan strategi pengawasan itu terkadang pihak stake holder (penentu kebijakan) tidak memiliki perencanaan yang matang akan strategi tersebut. Akibatnya, struktur pelaksanaan strategi program tidak berjalan sesuai dengan harapan. (wawancara, Oktober 2018)

Lebih lanjut mengungkapkan informan sebagai berikut:

......terkadang kita sebagai pengelolah bingung menentukan langkah dan arah kegiatan, hal itu terjadi karena strategi yang diamanahkan terkadang tidak didasarkan atas perencaanaan yang matang. Akibatnya kegiatan kita sepertinya tiba masa tiba akal. Kenyataan ini berdampak pada pelaksanaan tugas yang hanya untuk memenuhi tugas dan amanat yang telah diberikan. (wawancara, Oktober 2018)

Uraian di atas menunjukkan bahwa dalam pelaksanaan supervisi selalu mengalami perubahan kebijakan. Akibatnya para pengawas sering mengalami kesulitan di dalam menterjemahkan kebijakan tersebut. Para supervisor beranggapan terkadang kebijakan yang satu belum dilaksanakan secara maksimal, muncul kebijakan baru yang ujungnya masih seperti itu, hanya saja teknik pelaksanaannya yang rumit. Kenyataan ini sering dianggap oleh para pengawas bahwa hanya memberikan beban kerja yang besar atau ganda.

Untuk mengatasi hal itu, maka penulis berpendapat bahwa sebuah kebijakan, sebaiknya direncanakan secara matang dan selayaknya diujicobakan pada suatu daerah. Karena tidak semua kebijakan itu dapat dilaksanakan secara merata. Banyak kendala yang kemungkinannya muncul bila kebijakan itu berlaku secara sentralisasi.

\section{c. Dukungan Pemimpin Lokal dan Nasional}

Keberhasilan kegiatan pengawas atau sebuah strategi sangat ditentukan oleh dukungan dari berbagai pihak. Dalam pelaksanaan kegiatan supervisi dukungan yang dimaksudkan adalah diharapkan muncul dari para pemimpin baik lokal maupun nasional. Wujud nyata dukungan itu dapat berupa pemberian reward (penghargaan) bagi para pengawas maupun guru yang berprestasi. Disamping itu juga dapat melakukan studi perbandingan (komparatif) keberbagai daerah atau bahkan negara-negara yang maju pendidikannya. Bahkan jika memungkinkan para pengawas uyang berprestasi diberikan tunjangan atau beasiswa untuk melanjutkkan pendidikanya ke jenjang yang lebih tinggi. Tentunya kebijakan-kebijakan itu merupan bentuk dukungan yang seharusnya diberikan kepada para pengawas yang berprestasi. 
Hasil pengamatan penulis menunjukkan bahwa dukungan pemimpin pada pengembangan kegiatan kepengawasan masih minim. Hal itu terlihat dari operasionalisasi kegiatan pengawas dilapangan. Banyak pengawas yang tidak memiliki sarana dan prasarana supervisi seperti; kendaraan, laktop. Akibatnya dalam melakukan operasinal kegiatannya ia harus berjalan kaki. Demikian pula ketika sampai di sekolah yang di tuju ia masih mengarahkan para guru secara manual. Pengamatan penulis ini diperkuat oleh hasil wawancara dengan seorang pengawas yang selengkapnya menyatakan sebagai berikut:

......upaya untuk melaksanakan kegiatan pembinaan kepada para guru telah banyak yang saya lakukan, ada yang telah dilaksanakan dan yang belum terlaksana. Yang belum terlaksana sebagian besar disebabkan oleh sarana untuk pemberian pelayanan yang masih terbatas. Saya memiliki laktop. Laktop tersebut dapat digunakan pada sekolah-sekolah tertentu. Kondisi seperti menghambat tugas saya dalam membina dan mengarahkan guru.(wawancara, Oktober 2018)

Pendapat lain dikemukakan oleh informan sebagai berikut:

...jabatan sebagai pengawas telah kujalani selama sepuluh tahun terakhir, dan kemungkinannya saya akan pensiun dijabatan ini. Tapi selama berkarir dikegiatan pengawas, saya tidak pernah diberikan kesempatan atau kemudahan untuk mengikuti program pendidikan yang lebih tinggi. (wawancara, Oktober 2018).

Atas dasar itu, menurut penulis sebaiknya dalam penyusunan rencana pengembangan, sebaiknya dilakukan perencanaan yang matang hal tersebut akan tercipta bila dilakukan melalui komunikasi yang intensif dengan berbagai pihak. Hanya dengan cara demikian para pemimpin dan pihak-pihak akan merasa terpanggil untuk membantu para pengawas dalam pelaksanaan tugasnya.

\section{d. Kemampuan Komunikasi Supervisor}

Dalam kaitan dengan kegiatan supervisi, kunci utama pelaksanaan dan keberhasilannya terletak pada para supervisornya. supervisor yang tanggap dan cakap dalam merencanakan strategi komunikasi yang akurat. Demikian pula sebaliknya, supervisor yang tidak tanggap akan lambat mengelola berbagai strategi yang cocok untuk pelaksanaan kegiatan supervisi.

Pelaksanaan kegiatan supervisi Sekolah Dasar di Kecamatan Sombaopu belum berjalan dengan baik, diakibatkan oleh para supervisor yang belum memahami dengan jelas cara berkomunikasi serta belum mampu 
menerjemahkan bentuk-bentuk komunikasi yang cocok untuk di gunakan dalam kegiatan supervisi. Hal tersebut dari komentar salah seorang guru (informan) sebagai berikut:

....banyak kendala yang kami hadapi dalam kegiatan supervisi. Salah satunya adalah para supervisi tidak mampu menyusun pesan yang sistematis dalam kegiatan itu, disamping itu, ia tidak mampu menggunakan dan merencanakan media yang cocok, bahwa pengawas sendiri tidak tanggap dan tidak mampu menterjemahkan kebijakan ke dalam bentuk-bentuk program. (wawancara, Oktober 2018)

Apa yang dikemukakan oleh informan di atas, diperkuat oleh hasil observasi penulis di lapangan. Tampak bahwa para pengawas dalam menyajikan pesan betul-betul tidak sistematis, dan bahakan tidak menggunakan media akibatnya kegiatan bimbingan dan pengarahan yang dilakukan bersifat ceramah. Akibatnya banyak guru yang tidak memahami secara jelas materi yang disajikan.

Hal lain yang ditemukan peneliti adalah para pengawas yang menggunakan gaya komunikasi fear appeal (ancaman) akibatnya guru selalu diliputi oleh perasaan takut untuk bertanya, pada hal sesungguhnya banyak persoalan yang yang menurutnya tidak dipahami sehingga ingin bertanya tapi takut menyampaikannya.

Oleh karena menurut penulis, sebaiknya para supervisor sebaiknya memiliki pengetahuan dan keterampilan komunikasi. Demikian pula ketika ia melakukan kegiatan supervisi ia harus menampakkan muka yang bersahabat.

\section{SIMPULAN}

\section{Kesimpulan}

Strategi komunikasi yang digunakan pengawas dalam melakukan supervisi meliputi komunikasi antarpribadi, komunikasi kelompok dan komunikasi massa.

Faktor yang mempengaruhi straegi komunikasi pengawas dalam melakukan supervisi meliputi Kejelasan peran dan tugas, Struktur Kebijakan, Kemampuan Komunikasi Supervisor Dukungan Pemimpin Lokal dan Nasional

\section{Saran}

Dalam kegiatan supervisi Kepala Sekolah tetap harus melakukan pengembangan yang lebih kreatif dalam menggunakan strategi komunikasi yang cocok terhadap pelaksanaan supervisi yang dilakukan..

Setiap lembaga pendidikan diharapkan kegiatan supervisinya dapat dilakukan dengan pendekatan strategi komunikasi baik secara personal maupun secara kelompok supaya kegiatan tersebut dapat lebih mudah untuk dilakukan serta setiap Kepala Sekolah selaku pelaksana supervisi harus mampu melakukan 
pendekatan ini sebagai tanggungjawab dalam peningkatan mutu pendidikan di sekolah yang disupervsi.

\section{DAFTAR PUSTAKA}

Amantebun. N. A. 1981. Supervisi pendidikan. Penuntun bagi para penilik, Pengawas, kepala sekolah dan guru-guru. Suri. Jakarta.

Arifin, Anwar. 2007. Profil Baru Guru dan Dosen Indonesia. Pustaka Indonesia Bekerjasama Pokja Diknas DPP Partai golkar. Jakarta

Boden, Margaret A. 1994. Piaget. Londong Fontana Press

Burton.W H. dan Brueckner, L.J. (1995) Supervision : A social Process. New York : Appleton Cnetury Croft. Inc.

Effendy, Onong Uchjana. 2006. Ilmu Komunikasi. Teori dan Praktek. PT. Rosdakarya. Bandung.

Mulyasa. E. 2009. Menjadi kepala sekolah Profesional. PT. Rosdakarya. Bandung.

Napitupulu, Seri Praktik Pendidikan . 2002. Komisi Nasional Indonesia untuk UNESCO bekerjaama dengan Direktorat Jenderal Pendidikan Dasar dan Menengah Bagian Proyek Publikasi dan Sosialisasi Pendidikan. Jakarta.

Kumar, Arvid (ed). 2000. Encylopedia of Mass Media and Communication. New Delhi: Anmol Publication Pvt. Ltd.

Pengaribuan, P. dkk (2005) Profesi Kependidikan: Bahan Perkuliahan Dasar Kependidikan Medan: Lembaga Pendidikan Tenaga kependidikan Unimed, Tidak diterbitkan.

Sagala syaiful. 2009. Kemampuan Profesional guru dan Tenaga kependidikan. Alfabet. Bandung.

---------------. 2007. Konsep dan makna Pembelajaran : untuk membantu memecahkan problematika belajar dan mengajar. Alfabet. Bandung.

Sanjaya. Djuarsa S. 1994. Modul. Teori Komunikasi. Universitas terbuka. Jakarta.

Sergiovanni, thomas J.et.al (1987) Education Governance and Administration. New Jersey: Prentice Hall. Inc. 
Sunarto, Kumanto. 1993. Pengantar Sosiologi. Lembaga Penerbitan Fakultas Ekonomi Universitas Indonesia. Jakarta.

Sutisna, oteng (1966) Teacher Organization and profesionalization of publik school teacher. Makalah persentasikan di hadapan Dr. H. M. Vollmer di Stanford University. Makalah tidak diterbitkan.

Suharsimi Arikunto. 2004. Dasar-dasar Supervisi. PT. Rineka Cipta. Jakarta.

Swardi, Manajemen Pembelajaran, 2007. Tempina Media Grafika. Surabaya.

Tenriningsi Andi. 2009. Supervisi Pengajaran, Motivasi Kerja, Kinerja Guru dan Prestasi Belajar siswa. Barru 